\title{
The process of acquiring civic competences by students in the school space - analysis of theoretical foundations ${ }^{1}$
}

\section{KEYWORDS}

social competences training, civic competences, social development, school, socialisation

\begin{abstract}
The article analyses three selected theories: the theory of communicative action proposed by Jürgen Habermas, the theory of social learning by Albert Bandura, as well as dramaturgical theory by Erving Goffman. The aim of the analysis was to find one leading theory of the process of acquiring civic competences. The selected theory should meet the set conditions that allow it to be used in school space. Civic competences are understood as a particular subtype of social competences, the acquisition of which is an important element of social development. The scope of the definition of civic competences depends on the theoretical approach adopted. School space is a community made up of students, teachers and parents, who focus on a common goal. This space is also where students' socialisation takes place. The analysis was carried out on the basis of 5 questions regarding the subject, determinants, mechanism, place in development, and criteria for verifying the process of acquiring civic competences by students in the school space. The answers to the questions listed in the table have become the criteria for the analysis. However, this analysis did not allow for choosing a leading theory. None of the theories has met all the conditions set.
\end{abstract}

Adam Mickiewicz University Press, pp. 143-159

ISSN 2300-0422. DOI 10.14746/kse.2019.15.10

ORCID: https://orcid.org/0000-0001-8476-9738

\section{Introduction}

In its 2006 recommendations on the development of key competences ${ }^{2}$ through lifelong learning, the European Parliament emphasises and defines the terms social

${ }^{1}$ The article was inspired by the book by Mariola Chomczyńska-Miliszkiewicz (2002).

2 The Recommendation of the European Parliament and of the Council lists 8 key competences:

1. communication in the mother tongue; 
competences and civic competences. It defines them collectively as "all forms of behaviour that equip individuals to participate in an effective and constructive way in social and working life, and particularly in increasingly diverse societies" (Recommendation 2006/962/EC of the European Parliament and of the Council). The development of key competences comprises improving one's knowledge, shaping appropriate attitudes and improving practical skills.

Subject literature covers a number of definitions of social competences from psychological, sociological, pedagogical, and economic perspectives, as well as in intuitive understanding in the colloquial discourse of mass culture. The term "civic competences" is much more recent and specific, but the number of its definitions has also been growing recently, and the reasons for this include the differences in interpretations of civic competences as being linked to or existing independently of a democratic system.

The term "social competences" was introduced to psychology by Robert White in 1959, defining it as "an organism's capacity to interact effectively with the environment" (White, 1959, p. 317). The circumstances of an individual's social activity can take on various forms, depending on:

- whether the interactions take place between two, or more people;

- the role of the participant: partner, observer, source or object of influence;

- is the social context - direct or indirect;

The diversity of social situations and spheres of social functioning proves that we cannot consider one general social competence, but instead we need to distinguish multiple types (Martowska, 2012), which may also include civic and political competences. We may also identify a number of characteristics of social competences common to multiple definitions. These include being goal-oriented, intentionality (Spitzberg, Cupach, 1989) and determination of effective behaviour in social situations (Frost, 2004). In this article, I posit that civic competences are a specific subtype of social competences, concerning situations that require cooperation with others for the common good, which are essential for active and democratic participation in society, since they enable individuals to reconcile actions undertaken for the benefit of the community with a sense of personal autonomy (Plecka et al., 2013). The exact scope of civic competences (knowledge, attitudes and skills) will vary depending on the chosen theoretical approach.

2. communication in foreign languages;

3. mathematical competence and basic competences in science and technology;

4. digital competence;

5. learning to learn;

6. social and civic competences;

7. sense of initiative and entrepreneurship;

8. cultural awareness and expression (2006/962/EC; $c f$. Bacia 2015). 
The aim of the socialisation process is for the individual to internalise social norms and identify with social models. The socialised individual thus becomes capable and willing to undertake various social roles (Czapów, 1974). The acquisition of social competences, which is sometimes referred to as social training (Matczak, 2001) is undoubtedly a part of this process. Social training may occur in one of two ways (Knopp, 2010). In a natural (informal) way, when it takes place in the process of upbringing or when the individual is dealing with difficult social situations and tasks in everyday life, as well as formally, when it takes the form of special training courses, interpersonal training sessions and workshops. The process of acquiring civic competences, which make up a particular subset of social competences, is also a part of the socialisation process. It can be presented from one of three perspectives.

1. As a specific form of training - when the model of the role of a citizen acquired in the process of socialisation stands out in a specific way from other social roles and behaviours, by distinguishing specific content and specific part of the whole process.

2. As identical to social training - when fulfilling the role of a citizen and any other role requires gaining exactly the same scope of social competences, and no specific content or specific part of the socialisation process for civic competences is distinguished.

3. As a parallel training - when in the process of social training detailed, differentiated competences needed to perform different roles are acquired in parallel, where specific content is distinguished, unlike specific elements of the socialisation process.

The presented three perspectives of perception of civic competence training in the process of socialisation determined the choice of theories analysed in this article. The first perspective encompassed the theory of communicative action, proposed by Jürgen Habermas (1999); the second perspective included the dramaturgic theory put forth by Erving Goffman (2008a, 2008b); the third perspective is based on the theory of social learning by Albert Bandera (2007).

The process of socialisation is always linked to a specific social space. This social space is understood as "the totality of dynamic relations between the forces within and outside the individual, in an environment in which the individual is actively involved" (Izdebska, 2015, p. 11). This space has a physical, material and mental dimension, and it enables parallel coexistence of many spaces of socialisation interactions (Matyjas, 2017). Family is the first and primary space of socialisation. As a child grows older, their spaces of socialisation expand, and the key ones include school and the local community. School is the next community encountered by the individual after the family (Forma, 2012). School space is a specific 
product of human culture and is an essential element of human life space, actively influencing its shape (Matyjas, 2012). It is not only the building, the quality of education, and organisation of extracurricular activities, but primarily a community made up of teachers, parents and students focused on a common goal. The community character of the school is a key condition for the subject (students) to identify with other participants of the social life at school (friends, teachers, parents) (Modrzewski, Śmiałek and Wojnowski, 2008).

Class is a distinctive feature of the school space. Class is a small social group (Mika, 1986) formed in an institutional way, with a dual social structure (formal and informal). Referring to the definition of a social group, Mieczysław Łobocki (1974) defined a class as a group consisting of students who interact with each other, with different positions and roles, as well as a common system of values and norms regulating their behaviour in matters relevant to the class. The class group also serves as an educational environment and a place where the process of transferring models of behaviour, moral norms and shaping attitudes takes place. As one of the elements of the school structure, the class is not isolated, and many activities are defined in advance by the rhythm of the life of the school as a whole. Zbigniew Zaborowski (1964) distinguishes several types of social relations in a class. Interpersonal contacts take place between individuals. Material relations are formed in the process of carrying out joint tasks, encompassing issues such as determining the scope of the task at hand, leadership and responsibility. Personal relationships are then formed on the basis of personal visions and emotional contacts between students, including acquaintances and friendships. Classes also feature intergroup relations, which may involve cooperation or competition between groups within a class (Krasuska-Betiuk, 2015). From this perspective, a well-organised class space offers a wide range of opportunities for informal training of social and civic competences. Class also enables us to successfully observe the mechanisms of Goffman's sociology of interaction (Goffman, 2006; Goffman, 2008a, 2008b).

As an educational institution, school pursues the goals of education and upbringing given to it by society. Both formal and informal forms of training of social competences - including civic competences, should take place there (Gindrich, 2015). The Recommendation of the European Parliament and of the Council (2006) indicates the necessity of prioritising the development of key competences in the education process. The development of social competences through school is additionally a statutory obligation. According to the definition contained in the Educational Law, upbringing comprises "supporting a child in the development towards full maturity in the physical, emotional, intellectual, spiritual and social 
spheres" (Article 3 of the Education Law Act, Dz. U. [Journal of Laws] of 2017, item 59).

By analysing selected theories, proposed by Habermas, Bandura, and Goffman, concerning the process of shaping social and civic competences, I am going to search for one theory that corresponds to the specificity of the process of socialisation in school space, which will make it possible to distinguish elements characteristic for the course of acquiring strictly civic competences at the same time, point to the factors that determine its effectiveness, and make it possible to involve all students in a class in the process of acquiring civic competences. The task of the socialisation environment is to create opportunities for both natural and organised social training of the individual, influencing the formation of needs and motivating values for interpersonal contacts (understood as entering social situations), as well as developing social and emotional skills that determine the effectiveness of the use of experiences (Martowska, 2012).

The theory in question should meet the following conditions in order to be applicable in the process of developing civic competences in the school space:

1. generality - it needs to exhaust the range of possible social situations requiring the use of civic competences;

2. specificity - it needs to make it possible to distinguish training of civic competences from training of other social competences;

3. universality - it should assume the possibility of including individuals with different levels of internal preparation in the training;

4. purposefulness - it should organise the socialisation process in a purposeful way for both formal and informal training;

5. determination - it should indicate favourable factors, namely internal and external determinants influencing the effectiveness of training;

6. empirical verifiability - it should be possible to measure the effectiveness of the training.

\section{The process of acquiring civic competences. Theoretical basis}

While exploring selected theoretical categories, I will use a pre-defined grid of criteria for the analysis of the socialisation process, which will enable me to compare and select the leading theory for planning the development of civic competences in the school space.

I posed five analytical questions, the answers to which will constitute the criteria sought in the analysed theories: 


\section{What is the subject of this process?}

Quoting Pierre Rosanvallon (2011), the democratic order can be interpreted in three aspects: as the space of expression, implication and intervention. Democracy of expression offers space to express common emotions, feelings and judgements. Democracy of implication enables citizens to get together and forms groups in order to work together. Democracy of intervention offers tools for joint action, enabling achieving common goals. These aspects define the required categories of civic competences, covering for example critical analysis of the circumstances at hand, activity and communication competences. Individual competence groups are linked to specific attitudes, such as tolerance, respect for the interaction partner, respect for freedom and human dignity.

\section{What are the factors (determinants) of this process?}

Social competences, regardless of how their structure is defined, are usually understood as dependent on certain dispositions, which allow us to succeed in interpersonal relationships. Exogenous (external) and endogenous (internal) factors influence the frequency and intensity of social contacts (motivation to engage in social situations) and are individual for each person (Gumienny, 2010). Internal factors comprise personality traits - the need for social approval, pragmatism, being direct, alexithymia, as well as temperament - activity, liveliness, endurance, emotional reactivity. External factors are the environment in humans are brought up and function (Tomorowicz, 2011).

\section{What is the mechanism of this process?}

Depending on the adopted perspective, the process of developing civic competences may be presented as either continuous or taking place in stages, lifelong or starting upon achieving a specific level of maturity by the individual; finite - based on achieving a specific set of competences by the individual; or infinite - based on continuous improvement through experiencing new situations; intentional - formal and/or controlled and unintentional - natural and spontaneous; dependent or independent of the organisation of the space in which it takes place.

\section{What is the relation between the development of civic competences and other areas of development?}

Raymond Cattell (1971) introduced the division of general intelligence into two factors: fluid and crystal intelligence (Strelau, 1997). According to this theory, 
fluid intelligence is impossible to learn, dependent on a genetic factor and conditioned by physiological processes taking place in the nervous system. It is shaped only up to a certain point of development and is independent of culture or education. In turn, crystal intelligence is a result of interaction of fluid intelligence with personal life experiences of every person, thus, it develops all the time under the influence of many experiences and learning processes. One of the dimensions of crystal intelligence is social intelligence.

\section{What are the criteria used to verify the process of acquiring civic com- petences?}

Regardless of the theoretical approach to the socialisation process, it is always a process causing positive changes in the social behaviour of an individual (Koperek, 2011). The results of the socialisation process can be observed from an objective standpoint - when the society is understood as the subject of the process, as well as subjective - when this concerns an individual. The verification of objective results of socialisation will be thus based on the examination of the effects of norms and models concerning the functioning of the community learned by the individual. Verification of subjective results of the socialisation process is an analysis of the course and effects of this process from the standpoint of the socialised subject, for example competences acquired by an individual, conditioning their behaviour.

\section{Jürgen Habermas' theory of communicative action ${ }^{3}$}

\section{What is the subject of this process?}

The subject of the socialisation process is the internalisation of roles in communicative action. Habermas assumes that in the process of socialisation individuals acquire a communication competence defined as "the command of the ideal language user over the constitutive universals for dialogue, regardless of the current limitations of the empirical circumstances" (Szahaj, 1990, p. 96). In Habermas' concept, these universals comprise expressions and phrases, which enable directing the interaction towards reaching understanding in the sense of a "cooperative process of interpretation" (Habermas, 1999), which means intersubjective recognition of claims to the validity of a given statement, Leading to a consensus

\footnotetext{
3 J. Habermas (1999). Teoria działania komunikacyjnego, Warsaw: PWN.
} 
based on a common conviction, not imposed by either party. The acquisition of communication competence by members of the society is essential for the revival and continued existence of a democratic public life, in which important matters are debated by citizens (Calhoun, 2002).

\section{What are the factors (determinants) of this process?}

For a communication activity to end in understanding, a number of conditions needs to be met, depending on both internal factors - rational motivation of each of the participants of the interaction, as well as external ones - the existence of an ideal communication situation. Understanding can only be reached if all participants follow the appropriate procedures in an interaction -

a. integrate their formal concepts of the worlds (subjective, objective and social), thus building a common system that provides a framework for interpretation;

b. intersubjectively recognise the validity of the claims they make as true, fair and sincere;

c. jointly negotiate the definitions of the situation.

The ideal communication situation postulated by Habermas ensures equal opportunities and equal choices for all participants of the communication act; however, it requires a number of conditions to be met first:

a. no one, who could make a significant contribution, can be excluded from participation in the communication act due to valid, but controversial claims;

b. everyone needs to have the same opportunities to express their opinion on a given matter;

c. all participants must speak their mind;

d. the outcome of a debate should be determined by the strength of the arguments, everybody has the right to criticise and

disprove arguments of other participants and formulate one's own.

\section{What is the mechanism of this process?}

The acquisition of communication competence takes place during the communicative action. The process of socialisation is based on continuous participation in communicative actions and self-improvement, and thus it takes place in stages, it is based on self-learning and is infinite. If any of the claims to validity are not explicitly confirmed or rejected, they become subjects of a debate, relying on 
the strength of the arguments presented. Reaching an understanding is possible thanks to the motivation of the participants of the act, who are guided not by an egocentric calculation of their own success, but by the possibility to achieve their own goals, thanks to aligning their actions with those of others on the basis of common definitions of the situation.

Communication acts are regulated by binding social norms and empowered by sanctions. These standards must be respected by at least two entities entering into joint communicative action. The validity of these standards is based on the "intersubjectivity of the understanding of intentions and on the universal nature of obligations" (Habermas, 1977, p. 355), and accepting these norms equips an individual with the discipline of personality structure.

\section{What is the relation between the development of civic competences and other areas of development?}

Acquiring communication competences is one of the elements of the socialisation process. It is possible thanks to the prior internalisation of social and cultural norms and the development of social competences enabling participation in communicative actions. The meeting of subjects in a communicative action is possible thanks to the existence of their common world: the world of life. The world of life is a system made up of three elements:

- culture - a source of knowledge and its interpretation for the participants of the interaction;

- society - a source of social bonds, ensuring solidarity and enabling belonging to social groups;

- competences of the subject - in particular language competences, which enable participants in interaction to take part in processes leading to understanding (Stasiuk, 2003).

\section{What are the criteria used to verify the process of acquiring civic com- petences?}

The author does not provide any verification criteria; other than setting the goal of the process of acquiring civic competences as the ideal of democratic public life. Thus, we may assume that this verification criterion will be included in an objective perspective in this case, and will be examined as the proximity to the achievement of the set goal - the current state of democratisation of public life. 


\section{Albert Bandura's theory of social learning ${ }^{4}$}

\section{What is the subject of this process?}

The subject of social learning in Albert Bandura's theory (2007) is the shaping of behaviours of an individual - learning and sustaining pro-social behaviour, combined with a change or disappearance of anti-social behaviour. People learn by drawing conclusions and consequences of their own behaviours, as well as by modelling. Modelling is based on constant social observation, which is how the individual acquires knowledge about the world, the community to which they belong, as well as the binding norms and values. Thanks to modelling, said individual acquires social skills (competences). These skills make it possible to respect social rules, understand social mechanisms and participate in interactions. These include, among others: knowledge of the rules governing interactions, communication skills, understanding what others are saying, ability to adapt to social expectations, exerting influence, etc. The most important functions of modelling include instruction, braking, acceleration, facilitation and emotional stimulation.

\section{What are the factors (determinants) of this process?}

Human behaviour is jointly determined both by the individual (internal factors), as well as its surroundings (external factors). Bandura also pointed out the phenomenon of reciprocal determinism. According to this phenomenon, the behaviours of an individual are influenced by their environment and they also have an impact on this very environment, determining to some extent the future impact of external factors on their behaviour. "In reality, human psychological functioning is based on a continuous, reciprocal interaction of personal and environmental determinants (Bandura, 2007, p. 29).

The effectiveness of social learning is influenced by three groups of factors:

a) characteristics of the model (observers are better influenced by a highly competent and knowledgeable person. Other key factors include social status, appearance, age, signs of achieving success, being an expert in the modelled field);

b) characteristics of the observer (the lower their self-confidence and self-esteem, the higher the tendency to imitate the behaviour of the successful model. The higher the expectation of self-efficacy, the greater the motivation to undertake and intensify behaviours. Other important factors include concentration and cognitive skills);

\footnotetext{
${ }^{4}$ A. Bandura (2007). Teoria społecznego uczenia się, Warsaw: PWN.
} 
c) the consequences of imitating the model perceived by the observer (the same behaviour may have negative or positive consequences in different social contexts).

\section{What is the mechanism of this process?}

Modelling is not a passive imitation of the behaviour exhibited by the model, since it requires involvement and creative activity of the observer, who needs to focus on the model's behaviour, remember this behaviour and try it out on one's own. The individual learns patterns of behaviour through observing the reactions of other people and the results of these reactions, using substitute reinforcement while observing others. At the beginning, however, they never attempt to perform the observed actions on their own, instead focusing only on analysing different ways of navigating a given situation. Thanks to abstract modelling - cognitive analysis of numerous behaviours exhibited by different models, an individual can detect important social contingencies. Social contingency is based on interdependence between behaviour and received reinforcement in a given social context. The detected dependencies are translated into the programming of the individual's own behaviour in various situations, as well as carrying out only behaviours expected to enable them to achieve some desired outcomes. Social learning is therefore not mechanical. It is a flexible, cognitive and holistic process. It depends not only on the behaviour of the models, but also on individual motivational and cognitive processes taking place in the mind of the observing individual.

\section{What is the relation between the development of civic competences and other areas of development?}

Modelling is a personal process. Different people may pay attention to different aspects of behaviour of the same model and translate them into various programming of their own behaviour. This results from individual differences in focus, cognitive skills, personality responding to given reinforcements, experiences, current motivation and other factors. Modelling enables some skills to be acquired more quickly and efficiently, which enhances the ability of an individual to operate in the surrounding environment and to acquire new skills. According to the author of the social learning theory, acting on purpose, anticipating the effects of these actions and modifying behaviours in line with one's image of them is possible thanks to the ability to use verbal and imaginary symbols. Of course, the scope of learning of the individual is directly correlated with the level of psycho-physical skills appropriate to their stage of development and life. 


\section{What are the criteria used to verify the process of acquiring civic com- petences?}

The author does not explicitly provide criteria for verifying the process of acquiring civic competences. Taking into account the mechanism and purpose of modelling - behavioural shaping through observation of consequences, a subjective perspective seems to be appropriate for verification of its efficacy. The evaluation of the efficacy of this process needs to be based on the analysis of specific competences acquired by the individual, conditioning their proper, pro-social behaviour in situations of civic activity.

\section{Erving Goffman's dramaturgical theory ${ }^{5}$}

\section{What is the subject of this process?}

The subject of the competence acquisition process is the individual's behaviour in the public situations occurring in everyday life. According to Goffman (2008), competences do not constitute the content of a given behaviour - the presented impressions, but the way it plays out - the impressions it evokes, or in other words, the way an actor is seen and judged by others. Social interactions include any and all situation, where at least one additional person (audience) is present, apart from the actor themselves. There is no need for direct contact between the participants of social interaction; their presence is enough. Behaviour in a situation of social interaction (a public situation) is not only a conversation with the use of verbal symbols, but any manifestation of body behaviour, gestures, facial expressions, scratching on the nose or refraining from it. A competent behaviour is one that fits in with the conventions adopted by the society and is considered "normal", which means that it does not interfere with the collective sense of security.

\section{What are the factors (determinants) of this process?}

The basic determinant is the presence of other people, which transforms every human activity into a performance. Goffman rejects macro-social determinism. He considers external factors such as the social system, social role or class to have a much weaker impact on the individual's behaviour than the sense of being observed. Human behaviour is determined on a micro-social level by conventions,

${ }^{5}$ E. Goffman (2008a). Człowiek w teatrze życia codziennego, Warsaw: Aletheia and E. Goffman (2008b). Zachowanie w miejscach publicznych, Warsaw: PWN. 
which govern interactions, defining what is "acceptable" and "normal". Conventions organise the order of interaction in a total way, and they govern every manifestation of behaviour of an individual at any time and in any place where at least one other person is present. Goffman also rejects internal determinism. In his observations, he is not at all interested in the inner world of the individual, in what they are experiencing or whether they are even aware of their roles. He claims that "self" hidden under the mask is not what affects the behaviour of the individual. "Self" is created in the act of play, and the individuals shape themselves through interaction.

\section{What is the mechanism of this process?}

Social functioning of an individual is a natural process of infinite, continuous overlapping of their conduct with the conduct of others. This process is based on a mechanism of shaping oneself (here and now) according to the expectations of the audience - the participants of the interaction. "The proper object of the study of interaction are not the individual and their psychology; rather, it is the syntactic relationship between the acts performed by different persons present in close vicinity to each other" (Goffman, 2006, p. 2). Goffman wrote about the behavioural reaction to the consciousness of being observed by others. The actor's task is to impose their definition of the situation on the audience. The audience rewards them with applause or jeering. Whether an actor adheres strictly to a script imposed by a social system or improvises does not have a strict impact on whether they will be able to "sell themselves" to the audience. Competence, understood as an effective performance, depends on the context of a particular situation.

\section{What is the relation between the development of civic competences and other areas of development?}

According to Goffman, the competent social behaviour of an individual is not hinged on their cognitive abilities and awareness of their role, but only the way their behaviour is perceived by the audience. Is it considered "normal"? Does it interfere with their sense of security? Conventions are a prerequisite for the coexistence of individuals on the basis of an "ad hoc consent", since they organise the order of interactions and decide public consent to a given behaviour in a given situation. The actor's acting skills evolve as a result of the countless daily public situations that they 1959.

${ }^{6}$ The original, untranslatable title of the work was: The Presentation of Self in Everyday Life, 
have to face. Knowledge of conventions also focus on the skill of social calculation, just like the ability to anticipate what behaviour is acceptable and desirable in a given situation. The greater the experience, the greater the ability to act.

\section{What are the criteria used to verify the process of acquiring civic com- petences?}

Goffman developed his theory based on his own observations, including a participatory observation of the social life of psychiatric hospital patients made during his residence at the Social and Environmental Research Laboratory of the National Institute of Mental Health in 1955-1956. The theory, which emerged on the basis of these observations assumes that the verification of the efficacy of the process of acquiring social competences (including civic ones) comes in the form of the reaction of the audience to the actor's behaviour - approval or disapproval, or recognising the actor as a member of a community or as a mad person. The perspective of verifying the efficacy of the process is thus both objective and subjective, since it assumes both an analysis of the actor's ability to meet the requirements of the audience and the observation of the behaviour of the audience taking care of their social sense of security.

Table 1. Comparative analysis of the theories of development of civic competences

\begin{tabular}{|l|l|l|l|}
\hline Subject & \multicolumn{1}{|c|}{ Habermas } & \multicolumn{1}{c|}{ Bandura } & \multicolumn{1}{c|}{ Goffman } \\
\hline Determinants & $\begin{array}{l}\text { internalisation of the role } \\
\text { tion competences }\end{array}$ & $\begin{array}{l}\text { modelling pro-social be- } \\
\text { haviours - competences } \\
\text { as social skills } \\
\text { and } \\
\text { external determinants }\end{array}$ & $\begin{array}{l}\text { behaviour in public sit- } \\
\text { uations - competence as } \\
\text { a skill to evoke the desired } \\
\text { effect in the audience }\end{array}$ \\
\hline Mechanism & $\begin{array}{l}\text { participation in commu- } \\
\text { nicative actions. } \\
\text { Process: staged, infinite, } \\
\text { self-learning }\end{array}$ & $\begin{array}{l}\text { committed observation. } \\
\text { Process: cognitive, holis- } \\
\text { tic, flexible }\end{array}$ & $\begin{array}{l}\text { shaping oneself according } \\
\text { to the expectations of } \\
\text { the audience. Process: } \\
\text { natural, infinite and } \\
\text { ism - the presence of an } \\
\text { audience }\end{array}$ \\
\hline $\begin{array}{l}\text { Place } \\
\text { in developmentinuous }\end{array}$ & $\begin{array}{l}\text { preliminary competenc- } \\
\text { es (e.g. linguistic) are } \\
\text { required }\end{array}$ & $\begin{array}{l}\text { preliminary competences } \\
\text { (e.g. generalisation and } \\
\text { abstract thinking) are } \\
\text { required }\end{array}$ & $\begin{array}{l}\text { no preliminary compe- } \\
\text { tences are required }\end{array}$ \\
\hline $\begin{array}{l}\text { Verification } \\
\text { criteria }\end{array}$ & $\begin{array}{l}\text { objective perspective } \\
\text { subjective perspective }\end{array}$ & $\begin{array}{l}\text { objective and subjective } \\
\text { perspective }\end{array}$ \\
\hline
\end{tabular}

Source: own compilation 
The analysed theories do not meet all six of the aforementioned conditions to be met by a theory, which could be applied in the process of developing civic competences in the school space. All the presented theories meet the condition of generality, since they cover a comprehensive range of possible social situations requiring the use of civic competences. The theories proposed by Bandura and Goffman in particular, do not meet the condition of specificity, since they do not particularly distinguish behaviours that require civic competences from other social behaviours. In Goffman's theory, every behaviour in a public situation is governed by exactly the same mechanism and always concerns only the individual. Habermas' theory does not satisfy the necessary condition of universality, since his theory allows only individuals at the appropriate level of communication and cognitive development as well as rational motivation to participate in the civic competence training. On the other hand, Habermas' theory fulfils the condition of purposefulness, as does Bandura's. This condition is not fulfilled by Goffman's theory. Goffman's theory also completely ignores the role of endogenous determinants. Habermas' and Bandura's theories attribute importance to both internal and external determinants of the process of acquiring civic competences. Bandura also points out to the significance of correlations between them.

None of the authors, whose theories were analysed, directly defined criteria for verification allowing us to measure the efficacy of training. It seems that in the case of Goffman's theory, which does not meet the condition of purposefulness, defining such criteria is impossible altogether. Concerning other theories, it would be possible to establish some criteria on the basis of theoretical analysis, as well as derived from school theory. This is a possible area for further research.

\section{Bibliography}

Bacia E., Gieniusz A.M., Makowski G., Pazderski F., Stronkowski P., Walczak B. (2015). Kształtowanie kompetencji społecznych i obywatelskich przez organizacje pozarzadowe w Polsce, Warsaw: Instytut Badań Edukacyjnych.

Bandura A. (2007). Teoria społecznego uczenia się, Warsaw: PWN.

Calhoun C.J. et al. (eds.) (2002). Contemporary sociological theory, Oxford: Blackwell.

Cattell, R. B. (1971). Abilities: their structure, growth and action. Boston: Houghton Mifflin Co.

Chomczyńska-Miliszkiewicz M. (2002). Edukacja seksualna w społeczeństwie współczesnym: konteksty pedagogiczne i psychospołeczne, Lublin: Wydawnictwo UMCS.

Czapów Cz. (1974). "Funkcjonalność instytucji socjalizujących.” [in:] A. Podgórecki (ed.), Socjotechnika. Funkcjonalność i dysfunkcjonalność instytucji, Warsaw: KiW.

Dziennik Ustaw [Journal of Laws] of 2017, item 59, Act of 14 December 2016. Educational Law. Retrieved from http://www.dziennikustaw.gov.pl, on 2018.05.18. 
Forma, P. (2012). Socjalizacja dziecka z rodziny wielodzietnej. Studium teoretyczno-empiryczne. Kielce: Wydawnictwo Uniwersytetu Jana Kochanowskiego.

Frost A. (2004). "The psychological assessment of emotional intelligence." [in:] J. C. Thomas (ed.), Comprehensive handbook of psychological assessment, vol. 4 (p. 203-213). New Jersey: Wiley.

Gindrich E \& P. (2015). Środowisko szkolne a nieprzystosowanie, http://pedagogikaspecjalna.tripod. com (retrieved on 13.05.2019)

Goffman E. (2006). Rytuat interakcyjny, Warsaw: PWN.

Goffman E. (2008a). Człowiek $w$ teatrze życia codziennego, Warsaw: Aletheia.

Goffman E. (2008b). Zachowanie w miejscach publicznych, Warsaw: PWN.

Gumienny B. (2010). Kompetencje społeczne niepelnosprawnych wychowanków domów dziecka, Rzeszów: Wyd. URz.

Habermas J. (1977). “Technika i nauka jako 'ideologia.” [in:] J. Szacki (ed.), Czy kryzys socjologii? (p. 342 - 360). Warsaw: Czytelnik.

Habermas J. (1999). Teoria działania komunikacyjnego, Warsaw: PWN.

Szahaj A. (1990). Krytyka, Emancypacja, Dialog. Jürgen Habermas w poszukiwaniu nowego paradygmatu teorii krytycznej, Poznań: Universitas.

Izdebska, J. (2015). "Wielowymiarowość przestrzeni życia współczesnego dziecka." Zagadnienia Społeczne, 2015 (4), p. 11-15.

Knopp, K. (2010). Inteligencja emocjonalna i możliwości jej rozwijania u dzieci i młodzieży, Warsaw: Wyd. UKSW.

Koperek A. (2011). "Socjalizacja jako społeczno-wychowawczy proces integracji jednostki ze społeczeństwem," Pedagogika Katolicka no. 1/2011, p. 261-265.

Krasuska-Betiuk M. (2015). "Interakcje w klasie szkolnej z perspektywy społecznych reprezentacji i oczekiwań interpersonalnych," Studia z teorii wychowania, vol. 6: 2015 (12), p. 49-77.

Łobocki M. (1974), Wychowanie w klasie szkolnej. Z zagadnień dydaktyki

grupowej, Warsaw: WSiP.

Martowska K. (2012). Psychologiczne uwarunkowania kompetencji społecznych. Retrieved from: http://www.liberilibri.pl. on 2018.05.18.

Matczak A. (2001). Kwestionariusz Kompetencji Społecznych (KKS). Podręcznik, Warsaw: Pracownia Testów Psychologicznych Polskiego Towarzystwa Psychologicznego,

Matyjas B. (2017). "Rodzina -szkoła - środowisko lokalne jako synergiczna przestrzeń socjalizacji," Horyzonty wychowania, p. 41-54. Retrieved from: https://horyzonty.ignatianum.edu.pl/ on 2018.05.18. DOI: 10.17399/HW.2017.163803

Mika S. (1986). Psychologia społeczna, Warsaw: PWN.

Modrzewski, J., Śmiałek, M.I. \& Wojnowski, K. (eds.). (2008). Relacje podmiotów (w) lokalnej przestrzeni edukacyjnej (inspiracje...), Poznań: Wyd. UA.

Plecka D., Turska-Kawa A., Wojtasik W. (2013). Obywatelskie kompetencje polityczne, Kultura i Edukacja, 2013; 3 (96), p. 73-94.

Rosanvallon P. (2011). Kontrdemokracja. Polityka w dobie nieufności, Wrocław: WN DSW.

Spitzberg R. H., Cupach W. R. (1989). Handbook of interpersonal competence research, New York: Springer.

Stasiuk K. (2003). Krytyka kultury jako krytyka komunikacji. Wrocław: Wyd. UWr.

Strelau J. (1997). Inteligencja człowieka, Warsaw: Żak.

Tomorowicz A. (2011). "Struktura kompetencji społecznych w ujęciu interakcyjnym," Psychiatria, 2011; 8 (3), p. 91-96. 
White, R. W. (1959). "Motivation reconsidered: The concept of competence." Psychological Review, 1959; 66 (5), p. 297-333.

Zaborowski Z. (1964). Stosunki społeczne w klasie szkolnej, Warsaw: PWN.

Recommendation of the European Parliament and of the Council of 18 December 2006 on key competences for lifelong learning (2006/962/EC), OJ L 394/10. Retrieved from: http://eur-lex.europa. eu on 2018.05.18. 
